\title{
Genetic polymorphisms and haplotypes of the organic cation transporter 1 gene (SLC22A1) in the Xhosa population of South Africa
}

\author{
Clifford Jacobs, Brendon Pearce, Mornè Du Plessis, Nisreen Hoosain and Mongi Benjeddou \\ Department of Biotechnology, University of the Western Cape, Cape Town, South Africa.
}

\begin{abstract}
Human organic cation transporter 1 is primarily expressed in hepatocytes and mediates the electrogenic transport of various endogenous and exogenous compounds, including clinically important drugs. Genetic polymorphisms in the gene coding for human organic cation transporter 1, SLC22A1, are increasingly being recognized as a possible mechanism explaining the variable response to clinical drugs, which are substrates for this transporter. The genotypic and allelic distributions of 19 nonsynonymous and one intronic SLC22A1 single nucleotide polymorphisms were determined in 148 healthy Xhosa participants from South Africa, using a SNAPshot ${ }^{\circledast}$ multiplex assay. In addition, haplotype structure for SLC22A1 was inferred from the genotypic data. The minor allele frequencies for S14F (rs34447885), P341L (rs2282143), V519F (rs78899680), and the intronic variant rs622342 were 1.7\%, 8.4\%, 3.0\%, and $21.6 \%$, respectively. None of the participants carried the variant allele for R61C (rs12208357), C88R (rs55918055), S189L (rs34104736), G220V (rs36103319), P283L (rs4646277), R287G (rs4646278), G401S (rs34130495), M440I (rs35956182), or G465R (rs34059508). In addition, no variant alleles were observed for A306T (COSM164365), A413V (rs144322387), M420V (rs142448543), I421F (rs139512541), C436F (rs139512541), V501E (rs143175763), or I542V (rs137928512) in the population. Eight haplotypes were inferred from the genotypic data. This study reports important genetic data that could be useful for future pharmacogenetic studies of drug transporters in the indigenous Sub-Saharan African populations.
\end{abstract}

Keywords: polymorphism, haplotype, population genetic structure, genotyping, genetic variability.

Received: October 19, 2013; Accepted: February 27, 2014.

\section{Introduction}

Membrane transporters play an important role in the metabolism of clinical drugs and endogenous compounds. Single nucleotide polymorphisms (SNPs) in ATP-binding cassette $(A B C)$ and solute carrier transporter $(S L C)$ genes have been increasingly recognized as a possible mechanism accounting for altered transport activity, which may have profound clinical implications (Leabman et al., 2003). In general, genetic factors are estimated to account for 15$20 \%$ of inter-individual variations in drug disposition and responses (Evans and Relling, 1999; Eichelbaum et al., 2006; Choi and Song, 2008). However, for certain drugs genetic factors can account for up to $95 \%$ of inter-individual variability in drug disposition and effect (Evans and Relling, 2004; Eichelbaum et al., 2006).

Polyspecifc organic cation transporters (OCTs) are involved in the sodium-independent electrogenic transport of small organic cations with different molecular structures (Koepsell et al., 2007). These organic cations include clini-

Send correspondence to Mongi Benjeddou. Department of Biotechnology, University of the Western Cape, Robert Sobukwe Road, Bellville 7535, Cape Town, South Africa. E-mail: mbenjeddou@uwc.ac.za. cally important drugs (e.g., metformin, cimetidine, procaindamide), endogenous compounds (e.g., dopamine, norephinephrine, and toxic substrates (e.g., tetraethyl ammonium, haloperidol-derived pyridinium metabolite, 1-methyl-4-phenylpyridinium) (Gorboulev et al., 1997). Based on their substrate properties and tissue distributions, OCT1-3 are thought to play important roles in the biliary and renal excretion of their substrates and the distribution of organic cationic drugs in the liver, kidney, heart, and brain (Jonker and Schinkel, 2004).

Human OCT1 is encoded by the SLC22A1 gene which is located on chromosome 6q26, and consists of 11 exons spanning approximately $37 \mathrm{~kb}$ (Koehler et al., 1997; Koepsell et al., 2007). OCT1 is primarily expressed in the sinusoidal or basolateral membrane of hepatocytes and is thought to play an important role in the hepatic uptake, distribution and excretion of clinically important drugs (Gorboulev et al., 1997; Zhang et al., 1997). Previous studies have shown that hOCT1 is highly polymorphic in ethnically diverse populations (Shu et al., 2003; Sakata et al., 2004; Kang et al., 2007).

These aforementioned reduced-function genetic variants were however primarily found in studies with European participants and have not been consistently replicated 
for other ethnic groups (Leabman et al., 2003; Chen et al., 2010). Recent reports using genome-wide polymorphisms suggested that: (i) genetic variation seen outside of Africa is generally a subset of the total genetic variation that exists within Africa, (ii) genetic diversity decreases with increased geographic distance from Africa, and (iii) linkage disequilibrium (LD) patterns increase proportionally to the distance from Africa (Jakobsson et al., 2008; Li et al., 2008; Tishkoff et al., 2009). Moreover, Rosenberg et al. (2002) found that there is greater genetic diversity among African populations compared to Caucasian or Asian populations (Rosenberg et al., 2002). However, despite Africa harboring a significant proportion of human genomic diversity, this genomic diversity is unfortunately relatively under-studied (Hardy et al., 2008; Tishkoff et al., 2009).

South Africa is home to a large number of indigenous and immigrant population groups (Hardy et al., 2008; Benjeddou, 2010). Amongst these are the Bantu-speaking populations such as the Xhosa, Zulu, and Sotho, which are believed to have originated approximately 3000-5000 years ago in West Africa between the present-day Cameroon and Nigeria (Lane et al., 2002; Berniell-Lee et al., 2009). The indigenous populations potentially contain a significant amount of genomic diversity (Hardy et al., 2008; Tishkoff et al., 2009). These populations include the Xhosa, historically indigenous to the Eastern Cape Province of South Africa, and the second largest ethnic grouping in the country making up an estimated 8 million or $17.6 \%$ of the South African population (Drögemöller et al., 2010; Warnich et al., 2011).

This genomic diversity could provide a wealth of information and knowledge, which could eventually be applied to aid our understanding of the impact of genetic variation on complex diseases such as cancer, diabetes mellitus, hypertension and the inter-individual variability in response of patients to drugs used in the treatment of these diseases. Although limited, studies that have been conducted in South Africa suggest that South African populations have unique genetic profiles which include novel and rare variants, with allele frequencies differing from each other and other African populations (Warnich et al., 2011).

Previous studies have shown that South African populations exhibit unique allele frequencies and novel genetic variation in pharmacogenetically relevant genes (Ikediobi et al., 2011). Nyakutira et al. (2008), for example, showed that the $C Y P 2 B 6^{*} 6$ allele occurs at a higher frequency in people of African origin compared to other population groups, and is associated with high blood concentrations of the anti-HIV drug efavirenz in this group (Nyakutira et al., 2008). In addition, African populations also have higher allele frequencies for two CYP2D6 variant alleles, $C Y P 2 D 6^{*} 17$ and $* 29$, which in part explain the high incidence of intermediate metabolizers (IMs) of substrate drugs in these populations (Matimba et al., 2009). In another study, Chigutsa et al. (2011) investigated the distribution of the organic anion transporter (OATP) gene SLCO1B1 rs4149032 polymorphism, and found that the variant allele occurred at a higher frequency in African populations than in Caucasians or Asians (Chigutsa et al., 2011). The rs4149032 polymorphism is associated with low blood concentrations of the anti-tuberculosis drug rifampicin, which requires the prescription of a higher dosage for people of African origin in order to reach the concentration target. These studies have primarily focused on variants in the drug metabolizing enzyme genes. Information on variants in drug transporter genes for South African populations is however limited or non-existent. Therefore, the aim of the study was to investigate the genotypic and allelic distributions of 19 nonsynonymous and one intronic $\operatorname{SNP}(\mathrm{s})$, and to infer the haplotype structure of the SLC22A1 gene in the Xhosa population. These SNPs include A306T (COSM164365), A413V (rs144322387), M420V (rs72552763), I421F (rs151333280), C436F (rs139512541), V501E (rs143175763), V519F (rs78899680), and I542V (rs137928512) for which, to our knowledge, no population data exist in the public domain.

\section{Materials and Methods}

\section{Subjects}

Samples were obtained from the participants with informed consent. This study was approved by the Senate Research Ethics Committee of the University of the Western Cape, South Africa. Biological samples were collected in the form of buccal swabs from 148 unrelated healthy volunteers from the Xhosa population. Ethnicity of volunteers was determined by self-report.

\section{DNA Extraction and SNP selection}

Genomic DNA was isolated from buccal swab samples using a standard salt-lysis protocol and stored frozen at $-20{ }^{\circ} \mathrm{C}$ until the time of genotyping (Leat et al., 2004a). A total of 20 OCT1 gene SNPs (19 nonsynonymous and 1 intronic) were selected for this study. SNPs were selected from the literature and the Ensembl database (Flicek et al., 2012). Variants A306T, A413V, M420V, C436F, I421F, V501E, V519F, and I542V were included in this study based on predicted effect on function, using the SIFT (Sorting Intolerant From Tolerant) program ( $\mathrm{Ng}$ and Henikoff, 2003; Kumar et al., 2009; Flanagan et al., 2010). To our knowledge no population data exist in the public domain for these variants.

\section{Primer design}

Multiplex PCR primers, listed in Table 1, were designed to have an annealing temperature between $55^{\circ} \mathrm{C}$ and $60{ }^{\circ} \mathrm{C}$ using Primer3 software. To test for possible nonspecific amplification, primers were aligned with the NCBI sequence databases using Basic Local Alignment Search 
Table 1 - OCT 1 Multiplex PCR primers.

\begin{tabular}{|c|c|c|c|c|}
\hline Primer name & Length & $\mathrm{T}_{\mathrm{m}}$ & Nucleotide sequence & Amplicon size \\
\hline \multirow[t]{2}{*}{ Exon 1} & 24 & 65.9 & $5^{\prime}$ - TGCTGAGCCATCATGCCCACCGTG - 3' & 255 \\
\hline & 21 & 62.8 & $5^{\prime}-$ GGACACAGCCAGACACCCACG - $3^{\prime}$ & \\
\hline \multirow[t]{2}{*}{ Exon 2} & 24 & 59.6 & $5^{\prime}$ - CтCtTGCCGtgGtatgACtgGCAg - $3^{\prime}$ & 162 \\
\hline & 23 & 57.9 & $5^{\prime}-$ CAgAgGGGCTTACCTGGACTGG - $3^{\prime}$ & \\
\hline \multirow[t]{2}{*}{ Exon 3} & 25 & 58.1 & 5'- CстсCAтGTCTCCTтCTCTCtGAAg - 3' & 207 \\
\hline & 25 & 57.2 & $5^{\prime}-$ CTGGCCTCATCCCCATGATAATTAC - 3' & \\
\hline \multirow[t]{2}{*}{ Exon 4} & 24 & 61.3 & $5^{\prime}-$ CCCGCATAACGTCCACACCTCCTG - 5' & 222 \\
\hline & 23 & 60.3 & $5^{\prime}-$ GTAGGCAGGAGGAAGGGCCTCAC - $3^{\prime}$ & \\
\hline \multirow[t]{2}{*}{ Exons 5 and 6} & 24 & 57.4 & $5^{\prime}$ - GAtAgtgatgagtgGtgttCGCAG - 3' & 503 \\
\hline & 21 & 62.7 & $5^{\prime}$ - GCGAGCGTGCTGAtTCTGCCT - 3' & \\
\hline \multirow[t]{2}{*}{ Exon 7} & 25 & 59.3 & $5^{\prime}$ - GACTTGAAACCTCCTCTTGGCTCAG - 3' & 298 \\
\hline & 25 & 64.2 & $5^{\prime}$ - TTCCCCACACTTCGATTGCCTGGGA - 3' & \\
\hline \multirow[t]{2}{*}{ Exon 8} & 25 & 67.6 & $5^{\prime}-$ GAAGCCCCCATCCACCACCCACACC - 3' & 181 \\
\hline & 25 & 63.4 & $5^{\prime}$ - GGCtACCCCTGTtCCATGCACtCAC - 3' & \\
\hline \multirow[t]{2}{*}{ Exon 9} & 22 & 62.4 & $5^{\prime}$ - AttGCATGGGCAACGGATGGCT - 3' & 615 \\
\hline & 25 & 67.8 & $5^{\prime}$ - CCATGCTGAGCCCACTGCCGAGCTG - $3^{\prime}$ & \\
\hline \multirow[t]{2}{*}{ Exon 10} & 23 & 60.6 & $5^{\prime}$ - ттсCтстстtтGgCtgGCtgTgA - $3^{\prime}$ & 621 \\
\hline & 24 & 60.5 & $5^{\prime}$ - ACTCCAGCAAACCTTGCTCTCTGT - 3' & \\
\hline \multirow[t]{2}{*}{ Exon 11} & 25 & 58.9 & 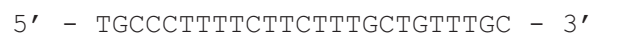 & 460 \\
\hline & 25 & 60.8 & $5^{\prime}$ - AgCACCAACAgCTTTCCCTAGATCG - 3' & \\
\hline \multirow[t]{2}{*}{ Intron 9} & 25 & 58.8 & $5^{\prime}$ - GAGTAGGAGGGGTtAAtAGAGAGAG - 3' & 236 \\
\hline & 27 & 65.7 & $5^{\prime}$ - GTAGCTGAGACTACATGCATGCACCAC - 3' & \\
\hline
\end{tabular}

Tool. Two SNaPshot ${ }^{\circledR}$ Multiplex systems were specifically designed for the study, successfully optimized and used for genotyping. The single base extension primer sets for multiplex 1 and 2 are listed in Tables 2 and 3.

\section{Multiplex PCR}

All the OCT1 exons and the portion of intron 9 spanning rs622342 were simultaneously amplified using the primers listed in Table 1 . The PCR reactions were per- formed in a $20 \mu \mathrm{L}$ volume, containing 20-50 ng of genomic DNA, 1 x Qiagen multiplex PCR master mix (Qiagen, Courtaboeuf, France) and $0.2 \mu \mathrm{M}$ of each primer. Cycling consisted of an initial 15 min activation step for HotStar $\mathrm{Taq}$ polymerase (Qiagen) at $95{ }^{\circ} \mathrm{C}$, followed by a total of 35 cycles using the following conditions: $94{ }^{\circ} \mathrm{C}$ denaturation for $30 \mathrm{~s}$, primer annealing at $60^{\circ} \mathrm{C}$ for $90 \mathrm{~s}$, and primer extension at $72{ }^{\circ} \mathrm{C}$ for $30 \mathrm{~s}$, and $15 \mathrm{~min}$ of final extension at $72{ }^{\circ} \mathrm{C}$ and a $4{ }^{\circ} \mathrm{C}$ holding step. PCR products were purified

Table 2 - OCT1 multiplex 1 single base extension primers.

\begin{tabular}{|c|c|c|c|c|c|}
\hline NCBI (dbSNP) & Amino acid change & Nucleotide change & Single base extension primers & dGACT & Size bp \\
\hline rs34447885 & $\mathrm{S} 14 \mathrm{~F}$ & $\mathrm{C} / \mathrm{T}$ & $5^{\prime}$ - TGACTAtTCtgGAgCAgGtTGGGGAGT - 3' & 13 & 40 \\
\hline rs34104736 & S189L & $\mathrm{C} / \mathrm{T}$ & $5^{\prime}$ - GAACTGTGCTGGTCAACGCGGTGT - 3' & 21 & 45 \\
\hline rs36103319 & G220V & $\mathrm{G} / \mathrm{T}$ & $5^{\prime}$ - GGTCAGCAAGGGCAACTGGATGGCTG -3' & 24 & 50 \\
\hline rs4646277 & $\mathrm{P} 283 \mathrm{~L}$ & $\mathrm{C} / \mathrm{T}$ & $5^{\prime}$ - GATAACAGCCACCGGGGGACACC - 3' & 32 & 55 \\
\hline rs34130495 & G401S & $\mathrm{G} / \mathrm{A}$ & $5^{\prime}$ - AGCCCTCATCACCATTGACCGCGTG - 3' & 35 & 60 \\
\hline rs72552763 & M420V & $\mathrm{A} / \mathrm{G}$ & $5^{\prime}$ - AACTTACCAGGTGAGATAAAAATCA - 3' & 40 & 65 \\
\hline rs35956182 & M440I & $\mathrm{G} / \mathrm{A}$ & $5^{\prime}$ - CATAATCATGTGTGTTGgCCGAAT - 3' & 46 & 70 \\
\hline rs34059508 & G465R & $\mathrm{G} / \mathrm{A}$ & $5^{\prime}-$ CCACAGGGAGGAACACACCATCACTC - 3' & 49 & 75 \\
\hline rs78899680 & V519P & $\mathrm{G} / \mathrm{T}$ & $5^{\prime}$ - CтAстTCtTCCAGAGACCAAGGGG - 3' & 56 & 80 \\
\hline rs137928512 & $\mathrm{I} 542 \mathrm{~V}$ & $\mathrm{~A} / \mathrm{G}$ & $5^{\prime}$ - CAGAGGTTTGGACCTTAAGGTAAA - 3' & 61 & 85 \\
\hline
\end{tabular}


Table 3 - OCT1 multiplex 2 single base extension primers.

\begin{tabular}{|c|c|c|c|c|c|}
\hline NCBI (dbSNP) & Amino acid change & Nucleotide change & Single base extension primers & dGACT & Size bp \\
\hline rs622342 & Intron & $\mathrm{A} / \mathrm{C}$ & $5^{\prime}$ - AтTTCTTCAAAтTTGATGAAAAстTC - 3' & 14 & 40 \\
\hline rs12208357 & $\mathrm{R} 61 \mathrm{C}$ & $\mathrm{C} / \mathrm{T}$ & $5^{\prime}$ - тCCTGGGGTGGCTGAGCTGAGCCAG - $3^{\prime}$ & 20 & 45 \\
\hline rs4646278 & $\mathrm{R} 287 \mathrm{G}$ & $\mathrm{C} / \mathrm{G}$ & $5^{\prime}$ - CAgtgtTtctтtтtтgtgAtAACAgCCACC - 3' & 20 & 50 \\
\hline rs55918055 & $\mathrm{C} 88 \mathrm{~S}$ & $\mathrm{~T} / \mathrm{A}$ & $5^{\prime}$ - TCCAGTCCACTTCATAGCGCCTGC - $3^{\prime}$ & 31 & 55 \\
\hline COSM164365 & $\mathrm{A} 306 \mathrm{~T}$ & $\mathrm{G} / \mathrm{A}$ & 5' - AgGAGGCAACTTCCCAтTCTTTTGAG - 3' & 34 & 60 \\
\hline rs2282143 & P341L & $\mathrm{C} / \mathrm{T}$ & $5^{\prime}$ - CTTCATTTGCAgACCTGTTCCGCACGC - 3' & 38 & 65 \\
\hline rs144322387 & $\mathrm{A} 413 \mathrm{~V}$ & $\mathrm{C} / \mathrm{T}$ & $5^{\prime}$ - CCCCATGGCCATGTCAAATTTGTTGG - $3^{\prime}$ & 44 & 70 \\
\hline rs151333280 & $\mathrm{I} 421 \mathrm{~F}$ & $\mathrm{~A} / \mathrm{T}$ & $5^{\prime}$ - CCAACTTACCAGGTGAGATAAAAA - 3' & 51 & 75 \\
\hline rs139512541 & $\mathrm{C} 436 \mathrm{~F}$ & $\mathrm{G} / \mathrm{T}$ & $5^{\prime}$ - GCACTGGTTAAACATCATAATCATGT - 3' & 54 & 80 \\
\hline rs143175763 & V501E & $\mathrm{T} / \mathrm{A}$ & $5^{\prime}-$ CACTCCCGCGGCAAGCAGGCCCAAC - 3' & 60 & 85 \\
\hline
\end{tabular}

to remove excess primers and un-incorporated dNTPs using an Exo/SAP protocol. The entire $20 \mu \mathrm{L}$ of PCR products were incubated with $0.5 \mu \mathrm{L}$ of Exo $1(20 \mathrm{U} / \mu \mathrm{L})$ enzyme (Thermo Scientific, Waltham, MA, USA) and $1 \mu \mathrm{L}$ of FastAP $(1 \mathrm{U} / \mu \mathrm{L})$ (Thermo Scientific) for $30 \mathrm{~min}$ at $37^{\circ} \mathrm{C}$ followed by $15 \mathrm{~min}$ at $80^{\circ} \mathrm{C}$ for enzyme inactivation. PCR quality and yield were checked using NanoDrop spectrophotometer.

\section{Multiplex minisequencing reactions}

Multiplex minisequencing was performed in a $10 \mu \mathrm{L}$ reaction volume using $3 \mu \mathrm{L}$ of a $1 / 10$ dilution of purified PCR products, $0.1-0.2 \mu \mathrm{M}$ of primers, and $5 \mu \mathrm{L}$ of SNaPshot ${ }^{\circledR}$ ready reaction mix (Applied Biosystems, Foster City, CA, USA). Sequence cycling consisted of 25 cycles of denaturation at $96^{\circ} \mathrm{C}$ for $10 \mathrm{~s}$, primer annealing at $50{ }^{\circ} \mathrm{C}$ for $5 \mathrm{~s}$, and primer extension at $60{ }^{\circ} \mathrm{C}$ for $30 \mathrm{~s}$. Postextension treatment was done by adding $1 \mathrm{U}$ of FastAP to the $10 \mu \mathrm{L}$ reaction volume and incubation at $37{ }^{\circ} \mathrm{C}$ for $30 \mathrm{~min}$ followed by $15 \mathrm{~min}$ at $80{ }^{\circ} \mathrm{C}$ to deactivate the enzyme.

\section{Electrophoresis of the minisequencing products}

The purified minisequencing products $(1 \mu \mathrm{L})$ were mixed with $8.7 \mu \mathrm{L}$ of HiDi formamide (Applied Biosystems) and $0.3 \mu \mathrm{L}$ of GeneScan-120 Liz size standard (Applied Biosystems) and denatured at $95{ }^{\circ} \mathrm{C}$ for $5 \mathrm{~min}$. The fluorescently labelled fragments were separated on $36 \mathrm{~cm}$ long capillaries in POP4 polymer on an ABI Prism 3500 Genetic Analyzer (Applied Biosystems). Data analyses were performed using GeneMapper ${ }^{\circledR}$ IDX Software Version 1.2 (Applied Biosystems).

\section{Statistical analysis}

Genotype and allele frequencies as well as the deviation from the Hardy-Weinberg Equilibrium were calculated using GenAlEx 6.5 software (Wigginton et al., 2005; Peakall and Smouse, 2012). Allele and genotype frequencies are given with binomial proportion $95 \%$ confidence intervals (CI) calculated according to the method of Wilson. The SHEsis analysis platform was used to infer the haplotype frequencies (Yong and Lin, 2005; Li et al., 2009). Statistical significance was defined as $\mathrm{p}<0.05$.

\section{Results}

The population studied consisted of 148 healthy Xhosa individuals between the ages of 18 and 61 years. There were 80 (54\%) female and 68 (46\%) male participants. The mean age of female participants was $25.3 \pm 9.0$ years, whereas male participants had a mean age of $24.8 \pm$ 7.7 years.

The genotype and allele frequencies of the 20 OCT1 gene SNPs investigated in the 148 Xhosa subjects are summarized in Table 4. The allelic frequency of each SNP was in HWE ( $p>0.05)$, except for rs622342. The genotype frequencies for rs622342 for homozygote wild-type (AA), heterozygote $(\mathrm{AC})$ and homozygote $(\mathrm{CC})$ were $63.5 \%$, $29.1 \%$, and $7.4 \%$, respectively. The MAF observed for rs622342 was $23 \%$. Sixteen out of the 19 investigated nonsynonymous SNPs were monomorphic in the Xhosa population. None of the participants were homozygous for the variant allele for S14F (rs34447885), P341L (rs2282143), and V519F (rs78899680). The S14F (rs34447885) variant genotype frequencies for homozygote wild-type (CC), heterozygote (CT) and homozygote (TT) were $96.6 \%, 3.4 \%$ and $0.0 \%$, respectively. The MAF observed for S14F (rs34447885) was 1.7\%. The P341L (rs2282143) variant genotype frequencies, on the other hand, for homozygote wild-type (CC), heterozygote (CT) and homozygote (TT) were 83.1\%, $16.9 \%$ and $0.0 \%$, respectively. The V519F (rs78899680) variant genotype frequencies for homozygote wild-type (CC), heterozygote (CT) and homozygote (TT) were $93.9 \%, 6.1 \%$ and $0.0 \%$, respectively.

The minor allele frequency (MAF) of a selected number of the investigated OCT1 gene SNPs in different ethnic groups are summarized in Table 5. SLC22A1 SNP variants 
Table 4 - Genotype and allele frequencies of OCT1 (SLC22A1) gene SNPs in 148 healthy Xhosa individuals.

\begin{tabular}{|c|c|c|c|c|c|c|c|c|}
\hline \multirow{2}{*}{$\begin{array}{l}\text { Amino acid } \\
\text { substitution }\end{array}$} & \multicolumn{4}{|c|}{ Observed genotype frequency } & \multicolumn{4}{|c|}{ Allele frequency } \\
\hline & dbSNP ID & Genotype & $\%$ & $95 \% \mathrm{CI}$ & Allele & $\%$ & $95 \% \mathrm{CI}$ & HWE (p) \\
\hline \multirow[t]{3}{*}{$\mathrm{S} 14 \mathrm{~F}$} & rs 34447885 & $\mathrm{CC}$ & 96.6 & $92.0-98.8$ & $\mathrm{C}$ & 98.3 & $96.3-99.1$ & 0.834 \\
\hline & & $\mathrm{CT}$ & 3.4 & $1.2-8.0$ & $\mathrm{~T}$ & 1.7 & $0.9-3.7$ & \\
\hline & & $\mathrm{TT}$ & 0.0 & $0.0-3.1$ & & & & \\
\hline \multirow[t]{3}{*}{$\mathrm{R} 61 \mathrm{C}$} & rs 12208357 & $\mathrm{CC}$ & 100.0 & $96.9-100.0$ & $\mathrm{C}$ & 100.0 & $98.4-100.0$ & \\
\hline & & $\mathrm{CT}$ & 0.0 & $0.0-1.3$ & $\mathrm{~T}$ & 0.0 & $0.0-1.6$ & \\
\hline & & $\mathrm{TT}$ & 0.0 & $0.0-1.3$ & & & & \\
\hline \multirow[t]{3}{*}{ C88R } & rs55918055 & $\mathrm{TT}$ & 100.0 & $96.9-100.0$ & $\mathrm{~T}$ & 100.0 & $98.4-100.0$ & \\
\hline & & TA & 0.0 & $0.0-1.3$ & A & 0.0 & $0.0-1.6$ & \\
\hline & & AA & 0.0 & $0.0-1.3$ & & & & \\
\hline \multirow[t]{3}{*}{ S189L } & rs 34104736 & $\mathrm{CC}$ & 100.0 & $96.9-100.0$ & $\mathrm{C}$ & 100.0 & $98.4-100.0$ & \\
\hline & & $\mathrm{CT}$ & 0.0 & $0.0-1.3$ & $\mathrm{~T}$ & 0.0 & $0.0-1.6$ & \\
\hline & & $\mathrm{TT}$ & 0.0 & $0.0-1.3$ & & & & \\
\hline \multirow[t]{3}{*}{$\mathrm{G} 220 \mathrm{~V}$} & rs36103319 & GG & 100.0 & $96.9-100.0$ & G & 100.0 & $98.4-100.0$ & \\
\hline & & GT & 0.0 & $0.0-1.3$ & $\mathrm{~T}$ & 0.0 & $0.0-1.6$ & \\
\hline & & $\mathrm{TT}$ & 0.0 & $0.0-1.3$ & & & & \\
\hline \multirow[t]{3}{*}{ P283L } & rs4646277 & $\mathrm{CC}$ & 100.0 & $96.9-100.0$ & $\mathrm{C}$ & 100.0 & $98.4-100.0$ & \\
\hline & & $\mathrm{CT}$ & 0.0 & $0.0-1.3$ & & 0.0 & $0.0-1.6$ & \\
\hline & & $\mathrm{TT}$ & 0.0 & $0.0-1.3$ & & & & \\
\hline \multirow[t]{3}{*}{ P341L } & rs2282143 & $\mathrm{CC}$ & 83.1 & $74.6-80.9$ & $\mathrm{C}$ & 91.6 & $87.0-93.7$ & 0.261 \\
\hline & & $\mathrm{CT}$ & 16.9 & $12.8-19.1$ & $\mathrm{~T}$ & 8.4 & $6.3-13.0$ & \\
\hline & & $\mathrm{TT}$ & 0.0 & $0.0-3.1$ & & & & \\
\hline \multirow[t]{3}{*}{ G401S } & rs34130495 & GG & 100.0 & $96.9-100.0$ & G & 100.0 & $98.4-100.0$ & \\
\hline & & GA & 0.0 & $0.0-1.3$ & A & 0.0 & $0.0-1.6$ & \\
\hline & & $\mathrm{AA}$ & 0.0 & $0.0-1.3$ & & & & \\
\hline \multirow[t]{3}{*}{ M440I } & rs35956182 & GG & 100.0 & $96.9-100.0$ & G & 100.0 & $98.4-100.0$ & \\
\hline & & GA & 0.0 & $0.0-1.3$ & A & 0.0 & $0.0-1.6$ & \\
\hline & & AA & 0.0 & $0.0-1.3$ & & & & \\
\hline \multirow[t]{3}{*}{ G465R } & rs 34059508 & GG & 100.0 & $96.9-100.0$ & G & 100.0 & $98.4-100.0$ & \\
\hline & & GA & 0.0 & $0.0-1.3$ & $\mathrm{~A}$ & 0.0 & $0.0-1.6$ & \\
\hline & & AA & 0.0 & $0.0-1.3$ & & & & \\
\hline \multirow[t]{3}{*}{ V519F } & rs78899680 & GG & 93.9 & $88.6-96.9$ & G & 97.0 & $94.2-98.5$ & 0.703 \\
\hline & & GT & 6.1 & $3.1-11.4$ & $\mathrm{~T}$ & 3.0 & $1.5-3.7$ & \\
\hline & & $\mathrm{TT}$ & 0.0 & $0.0-3.1$ & & & & \\
\hline \multirow[t]{3}{*}{ Intronic SNP } & rs622342 & AA & 64.2 & $54.7-70.3$ & A & 78.4 & $72.2-81.8$ & 0.048 \\
\hline & & $\mathrm{AC}$ & 28.4 & $22.3-36.9$ & $\mathrm{C}$ & 21.6 & $18.2-23.0$ & \\
\hline & & $\mathrm{CC}$ & 7.4 & $6.1-16.2$ & & & & \\
\hline \multirow[t]{3}{*}{$\mathrm{R} 287 \mathrm{G}$} & rs4646278 & $\mathrm{CC}$ & 100.0 & $96.9-100.0$ & $\mathrm{C}$ & 100.0 & $98.4-100.0$ & \\
\hline & & CG & 0.0 & $0.0-1.3$ & $\mathrm{G}$ & 0.0 & $0.0-1.6$ & \\
\hline & & GG & 0.0 & $0.0-1.3$ & & & & \\
\hline \multirow[t]{3}{*}{ I $542 \mathrm{~V}$} & rs137928512 & AA & 100.0 & $96.9-100.0$ & A & 100.0 & $98.4-100.0$ & \\
\hline & & AG & 0.0 & $0.0-1.3$ & G & 0.0 & $0.0-1.6$ & \\
\hline & & GG & 0.0 & $0.0-1.3$ & & & & \\
\hline \multirow[t]{3}{*}{$\mathrm{M} 420 \mathrm{~V}$} & rs 142448543 & $\mathrm{AA}$ & 100.0 & $96.9-100.0$ & A & 100.0 & $98.4-100.0$ & \\
\hline & & $\mathrm{AG}$ & 0.0 & $0.0-1.3$ & G & 0.0 & $0.0-1.6$ & \\
\hline & & GG & 0.0 & $0.0-1.3$ & & & & \\
\hline
\end{tabular}


Table 4 (cont.)

\begin{tabular}{|c|c|c|c|c|c|c|c|c|}
\hline \multirow{2}{*}{$\begin{array}{l}\text { Amino acid } \\
\text { substitution }\end{array}$} & \multicolumn{4}{|c|}{ Observed genotype frequency } & \multicolumn{4}{|c|}{ Allele frequency } \\
\hline & dbSNP ID & Genotype & $\%$ & $95 \% \mathrm{CI}$ & Allele & $\%$ & $95 \% \mathrm{CI}$ & $\operatorname{HWE}(\mathrm{p})$ \\
\hline \multirow[t]{3}{*}{ A413V } & rs144322387 & $\mathrm{CC}$ & 100.0 & $96.9-100.0$ & $\mathrm{C}$ & 100.0 & $98.4-100.0$ & \\
\hline & & $\mathrm{CT}$ & 0.0 & $0.0-1.3$ & $\mathrm{~T}$ & 0.0 & $0.0-1.6$ & \\
\hline & & $\mathrm{TT}$ & 0.0 & $0.0-1.3$ & & & & \\
\hline \multirow[t]{3}{*}{$\mathrm{I} 421 \mathrm{~F}$} & rs151333280 & AA & 100.0 & $96.9-100.0$ & A & 100.0 & $98.4-100.0$ & \\
\hline & & AT & 0.0 & $0.0-1.3$ & $\mathrm{~T}$ & 0.0 & $0.0-1.6$ & \\
\hline & & TT & 0.0 & $0.0-1.3$ & & & & \\
\hline \multirow[t]{3}{*}{$\mathrm{C} 436 \mathrm{~F}$} & rs139512541 & GG & 100.0 & $96.9-100.0$ & G & 100.0 & $98.4-100.0$ & \\
\hline & & GT & 0.0 & $0.0-1.3$ & $\mathrm{~T}$ & 0.0 & $0.0-1.6$ & \\
\hline & & TT & 0.0 & $0.0-1.3$ & & & & \\
\hline \multirow[t]{3}{*}{ V501E } & rs143175763 & TT & 100.0 & $96.9-100.0$ & $\mathrm{~T}$ & 100.0 & $98.4-100.0$ & \\
\hline & & TA & 0.0 & $0.0-1.3$ & A & 0.0 & $0.0-1.6$ & \\
\hline & & AA & 0.0 & $0.0-1.3$ & & & & \\
\hline \multirow[t]{3}{*}{ A306T } & COSM164365 & GG & 100.0 & $96.9-100.0$ & G & 100.0 & $98.4-100.0$ & \\
\hline & & GA & 0.0 & $0.0-1.3$ & A & 0.0 & $0.0-1.6$ & \\
\hline & & AA & 0.0 & $0.0-1.3$ & & & & \\
\hline
\end{tabular}

R61C (rs12208357), C88R (rs55918055), S189L (rs34104736), G401S (rs34130495), and G465R (rs34059508) were not observed in the Xhosa, Sub-Saharan or Asian populations. However, it was observed in Caucasian populations. Two SLC22A1 SNP variants, S14F (rs34447885) and V519F (rs78899680), were only observed in the Xhosa and the other Sub-Saharan populations, but not in the Asian or Caucasian populations. Inferred haplotypes are listed in Table 6.

\section{Discussion}

Single nucleotide polymorphisms in OCT1 have been increasingly recognized as a possible mechanism explaining inter-individual variation in drug response (Leabman et $a l ., 2003)$. In this study we determined the allelic frequency of 20 SNPs in the OCT1 gene of 148 healthy individuals of the Xhosa population of South Africa, and the data was compared with other published studies. No polymorphisms were observed for the Xhosa population for 16 out of the 20 SNPs investigated in this study. In a previous study aimed at the development of male specific genotyping systems for use in sexual assault cases in South Africa, low levels of polymorphism were also observed for the Xhosa population (Leat et al., 2004a,b, 2007).

hOCT1 carrying the S14F (rs34447885) substitution was previously shown to exhibit an increased uptake of the prototypical organic cation $\mathrm{MPP}^{+}$(Shu et al., 2003). However, in a subsequent study by Shu et al. (2007) it was shown that the S14F variant displayed a reduced uptake of the anti-diabetic drug metformin which, was attributed to a reduction in the transporter's $\mathrm{V}_{\max }$ for metformin (Shu et al., 2007). The MAF of S14F (rs34447885) for the Xhosa population $(2.0 \%)$ was similar to that of African-Americans (3\%) (Shu et al., 2003) and of two other sub-Saharan African populations, the Luhya in Webuye, Kenya (3\%) and the Yoruba in Ibadan. Nigeria (2.0\%). However, the MAF was significantly higher than that observed in Caucasians $(0.0 \%)$ and Asians $(0 \%)$. Therefore, it is possible to expect that drugs which are substrates of OCT 1 could have different response profiles in the Xhosa population compared to Caucasian and Asian populations.

Previous studies have found that hOCT1 R61C (rs12208357) and G401S (rs34130495) variants showed reduced transport of the prototypical organic cation $\mathrm{MPP}^{+}$ (Shu et al., 2003). In addition, it was shown that these variants exhibited reduced transport of metformin (Shu et al., 2007). Furthermore, the R61C (rs12208357) variant has been reported to be strongly correlated with low OCT1 protein expression in liver tissues of a 150 Caucasian subjects (Nies et al., 2009). Moreover, these reduced-function variants were associated with an increase in the renal clearance of metformin (Tzvetkov et al., 2009). Both these variants are frequently observed in Caucasian populations with MAF of $7.2 \%$ and $4 \%$, respectively (Shu et al., 2003). In contrast, none of these variants were observed for the Xhosa, Luhya, Yoruba, African-Americans or any of the Asian populations.

In Xenopus laevis oocytes expression systems, the uptake of the prototypical organic cation $\mathrm{MPP}^{+}$by the C88R (rs55918055) variant transporter was reduced to $1.4 \%$ compared with the reference, whereas serotonin uptake was reduced to only $13 \%$ of the wild-type (Kerb et al., 2002). The MAF for C88R (rs55918055) in a Caucasian 


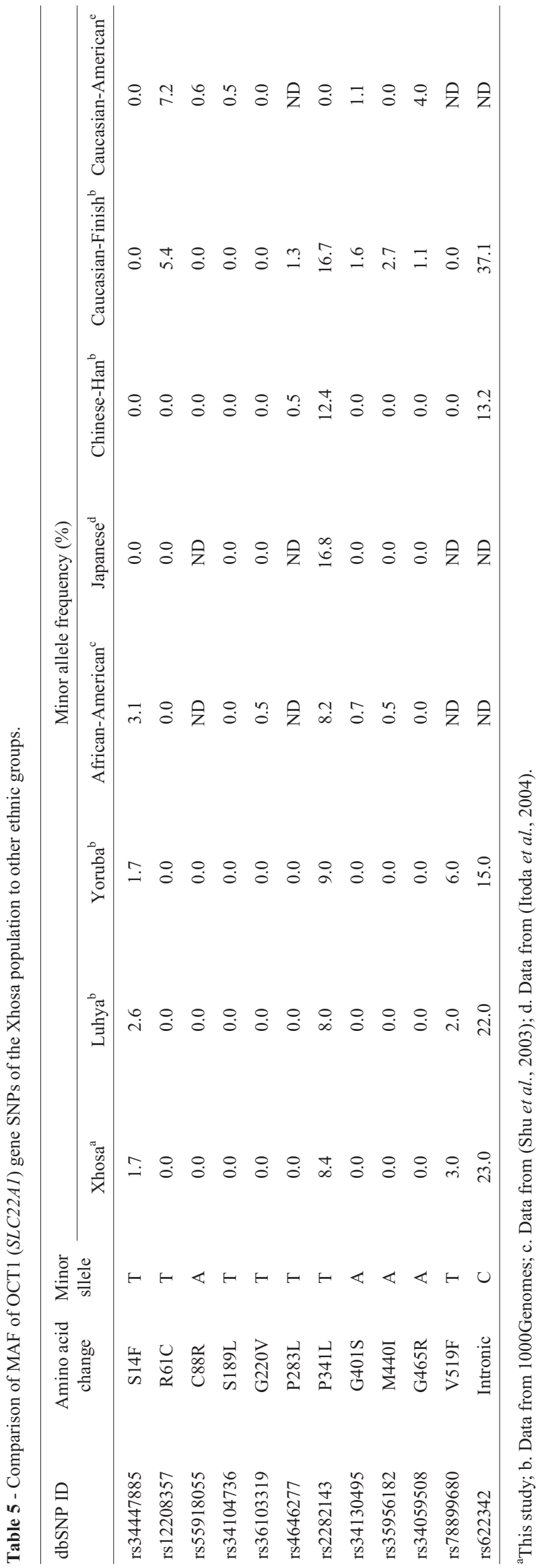

Table 6 - Haplotype structure defined by 20 SNPs in the $S L C 22 A 1$ gene in the Xhosa population.

\begin{tabular}{llc}
\hline Haplotype no. & Haplotypes $^{\mathrm{a}}$ & Frequency $\%$ \\
\hline 1 & CCTCGCCGCGCAAGGAGTGA & 69.4 \\
2 & CCTCGCCGCGCAAGGAGTTA & 2.8 \\
3 & CCTCGCCGCGCAAGGCGTGA & 17.6 \\
4 & CCTCGCCGTGCAAGGAGTGA & 5.0 \\
5 & CCTCGCCGTGCAAGGCGTGA & 3.2 \\
6 & CCTCGCCGTGCAAGGCGTTA & 0.2 \\
7 & TCTCGCCGCGCAAGGAGTGA & 1.1 \\
8 & TCTCGCCGCGCAAGGCGTGA & 0.6 \\
& Total & 99.9 \\
\hline
\end{tabular}

${ }^{a}$ Haplotype sequences are based on the position of SNPs on chromosome 6 .

population was observed at $6.2 \%$ by Kerb et al. (2002), compared to $0.0 \%$ for the Xhosa population in this study.

The OCT1 variants G220V (rs36103319) and G465R (rs34059508) were first identified as non-functional variants. The G220V (rs36103319) variant has thus far only been observed in the African American population with MAF of $0.5 \%$, whereas, the G465R (rs34059508) was only observed in the Caucasian population at a MAF of $4.0 \%$. Moreover, G465R (rs34059508) was associated with reduced localization at the basolateral membrane (Shu et al., 2007). However, none of these non-functional variants were observed in this study for the Xhosa population. These variants were also not observed in other African populations or in any of the Asian populations.

The allele frequency of P341L (rs2282143) in the Xhosa population $(8.4 \%)$ was similar to those of other Sub-Saharan African populations, lower than the Asian populations, and significantly higher than that of the Caucasian populations (Table 5). Functional transport assays conducted in vitro have shown that the P341L (rs2282143) variant results in a decrease rate of MPP+ transport, and has no effect on the transport of the anti-diabetic drug metformin (Sakata et al., 2004; Shu et al., 2007). Thus, impaired transport activities related to the P341L (rs2282143) SNP may differ between Africans, Asians, and Caucasians, with consequent effects on the pharmacokinetics/pharmacodynamics of certain substrates (Kang et al., 2007).

The P283L (rs4646277) variant was first described in a Japanese population and was shown to have reduced transport activity despite similar protein expression levels of the plasma membrane (Takeuchi et al., 2003; Sakata et al., 2004). The P283L (rs4646277) variant was subsequently also found in other Asian populations with an allele frequency of $1.3 \%$ in a Korean population and did not differ significantly from those of Chinese and Vietnamese populations (Kang et al., 2007). This variant was however not observed in the Xhosa population or any of the other Afri- 
can populations nor in any of the Caucasian populations (Table 5).

The intronic SNP rs622342 was first reported by Becker et al. (2009) in a group of Dutch diabetic patients with a MAF of $37.0 \%$. In contrast, the MAF for this variant in the Xhosa population was lower (21.6\%) (Becker et al., 2009). Moreover, these authors concluded that an association existed between genetic variation in the gene encoding for the OCT1 transporter protein and the glucose lowering effect of metformin in diabetes mellitus patients, and that metformin therapy was less effective in patients carrying the minor $\mathrm{C}$ allele (Becker et al., 2009). In a subsequent study, by the same group, it was shown that the effect of the MATE1 rs2289669 polymorphism on the glucose lowering effect of metformin was larger in patients with the OCT1 rs622342 CC genotype than those with the AA genotype (Becker et al., 2010).

In the present study, the nonsynonymous SNP V519F (rs78899680) was also genotyped and the observed MAF was $3.0 \%$. This value was higher than that of the Luhya $(2.0 \%)$, a population from Eastern Africa, and lower than that of the Yoruba (6.0\%) of Western Africa (Table 5). However, this variant was not observed in any of the Caucasian or Asian populations, indicating that it may be specific to African populations. The impact of this variant on transport function or drug efficacy has not yet been determined and requires further investigation.

It is well known that individual variation in drug response can be attributed to specific genetic variants. Moreover, it is believed that the incorporation of haplotypes in pharmacogenetic studies will provide a more complete picture of loci that are relevant in the practice of "genetic medicine" both at an individual or population level (Crawford and Nickerson, 2005). In this study, the haplotype structure defined by 20 SNPs in the $S L C 22 A 1$ gene was inferred for the investigated population. The most frequently observed haplotypes were CCTCGCCGCGCAAGGAGTGA (69.4\%), CCTCGCCGCGCAAGGCGTGA (17.6\%), and CCTCGCCGTGCAAGGAGTGA (7.0\%).

Although Africa is the continent where the burden of disease is the heaviest, research and clinical trials are predominantly performed on Western European and North American Caucasian, and Asian populations. The results of these studies are often extrapolated for use and interpretation in African populations, which contributes to poor treatment response and occurrence of adverse drug reactions in the genetically diverse African populations. Thus, OCT 1 variant alleles which are commonly/only found in African populations will/may have a profound impact on organic cationic drug transport efficacy and toxicity. Given that organic cationic drugs are used in the treatment of diseases such as Type II diabetes mellitus, various cancers, and HIV, these variant alleles may impact profoundly on healthcare provided across the African continent. Therefore, given the aforementioned reasons studies such as this is invaluable in the generation of useful pharmacogenetic information specific for African populations.

\section{Conclusions}

To our knowledge, this is the first study that investigated the allele and genotype frequency distributions of SNPs in the OCT1 gene of the Xhosa population. This study also reports the observed haplotypes in the investigated population. It has also been shown that reducedfunction nonsynonymous SNPs in the OCT1 gene found in Caucasian and Asian populations are absent from the Xhosa population. We have shown that, although MAF observed for the Xhosa population is largely similar to other African populations, differences exist that may translate into differences in organic cationic drug transport between these ethnic groups. These variations may translate into differences in the transport and efficacy of organic cationic drugs commonly used for the treatment of diseases prevalent in Africa. However, it should be noted that this was only a descriptive study and that no associations are made between any diseases or treatment outcomes. This study contributes towards filling the gap that exists with regards to genetic information about important variations in organic cation transporter genes for the indigenous populations of South Africa.

\section{Acknowledgments}

This study was funded by the Medical Research Council of South Africa (MRC), the National Research Foundation of South Africa (NRF), and the University of the Western Cape. We would also like to extend a special thanks to the sample donors.

\section{References}

Becker M, Visser L, van Schaik R, Hofman A, Uitterlinden A and Stricker B (2009) Genetic variation in the organic cation transporter 1 is associated with metformin response in patients with diabetes mellitus. Pharmacogenomics J 9:242247.

Becker ML, Visser LE, van Schaik RH, Hofman A, Uitterlinden AG and Stricker BHC (2010) Interaction between polymorphisms in the OCT1 and MATE1 transporter and metformin response. Pharmacogenet Genomics 20:38-44.

Benjeddou M (2010) Solute carrier transporters: Pharmacogenomics research opportunities in Africa. Afr J Biotechnol 9:9191-9195.

Berniell-Lee G, Calafell F, Bosch E, Heyer E, Sica L, Mouguiama-Daouda P, Van Der Veen L, Hombert J-M, QuintanaMurci L and Comas D (2009) Genetic and demographic implications of the Bantu expansion: Insights from human paternal lineages. Mol Biol Evol 26:1581-1589.

Chen L, Takizawa M, Chen E, Schlessinger A, Segenthelar J, Choi JH, Sali A, Kubo M, Nakamura S, Iwamoto Y, et al. (2010) Genetic polymorphisms in organic cation transporter 1 (OCT1) in Chinese and Japanese populations exhibit altered function. J Pharmacol Exp Ther 335:42-50. 
Chigutsa E, Visser ME, Swart EC, Denti P, Pushpakom S, Egan D, Holford NH, Smith PJ, Maartens G, Owen A, et al. (2011) The SLCO1B1 rs4149032 polymorphism is highly prevalent in South Africans and is associated with reduced rifampin concentrations: Dosing implications. Antimicrob Agents Chemother 55:4122-4127.

Choi M-K and Song I-S (2008) Organic cation transporters and their pharmacokinetic and pharmacodynamic consequences. Drug Metab Pharmacokinet 23:243-253.

Crawford DC and Nickerson DA (2005) Definition and clinical importance of haplotypes. Annu Rev Med 56:303-320.

Drögemöller BI, Wright GE, Niehaus DJ, Koen L, Malan S, Da Silva DM, Hillermann-Rebello R, La Grange AM, Venter M and Warnich L (2010) Characterization of the genetic profile of CYP2C19 in two South African populations. Pharmacogenomics 11:1095-1103.

Eichelbaum M, Ingelman-Sundberg M and Evans WE (2006) Pharmacogenomics and individualized drug therapy. Annu Rev Med 57:119-137.

Evans WE and Relling MV (1999) Pharmacogenomics: Translating functional genomics into rational therapeutics. Science 286:487-491.

Evans WE and Relling MV (2004) Moving towards individualized medicine with pharmacogenomics. Nature 429:464468.

Flanagan SE, Patch A-M and Ellard S (2010) Using SIFT and PolyPhen to predict loss-of-function and gain-of-function mutations. Genet Test Mol Biomarkers 14:533-537.

Flicek P, Amode MR, Barrell D, Beal K, Brent S, Carvalho-Silva D, Clapham P, Coates G, Fairley S Fitzgerald S, et al. (2012) Ensembl 2012. Nucleic Acids Res 40:D84-D90.

Gorboulev V, Ulzheimer JC, Akhoundova A, Ulzheimer-Teuber I, Karbach U, Quester S, Baumann C, Lang F, Busch AE and Koepsell H (1997) Cloning and characterization of two human polyspecific organic cation transporters. DNA Cell Biol 16:871-881.

Hardy B-J, Séguin B, Ramesar R, Singer PA and Daar AS (2008) South Africa: From species cradle to genomic applications. Nat Rev Genet 9:S19-S23.

Ikediobi O, Aouizerat B, Xiao Y, Gandhi M, Gebhardt S and Warnich L (2011) Analysis of pharmacogenetic traits in two distinct South African populations. Hum Genomics 5:265282.

Jakobsson M, Scholz SW, Scheet P, Gibbs JR, VanLiere JM, Fung H-C, Szpiech ZA, Degnan JH, Wang K, Guerreiro R et al. (2008) Genotype, haplotype and copy-number variation in worldwide human populations. Nature 451:998-1003.

Jonker JW and Schinkel AH (2004) Pharmacological and physiological functions of the polyspecific organic cation transporters: OCT1, 2, and 3 (SLC22A1-3). J Pharmacol Exp Ther 308:2-9.

Kang H-J, Song I-S, Shin HJ, Kim W-Y, Lee C-H, Shim J-C, Zhou H-H, Lee SS and Shin J-G (2007) Identification and functional characterization of genetic variants of human organic cation transporters in a Korean population. Drug Metab Dispos 35:667-675.

Kerb R, Brinkmann U, Chatskaia N, Gorbunov D, Gorboulev V, Mornhinweg E, Keil A, Eichelbaum M and Koepsell H (2002) Identification of genetic variations of the human organic cation transporter hOCT1 and their functional consequences. Pharmacogenet Genomics 12:591-595.
Koehler M, Wissinger B, Gorboulev V, Koepsell H and Schmid M (1997) The two human organic cation transporter genes SLC22A1 and SLC22A2 are located on chromosome $6 \mathrm{q} 26$. Cytogenet Genome Res 79:198-200.

Koepsell H, Lips K and Volk C (2007) Polyspecific organic cation transporters: Structure, function, physiological roles, and biopharmaceutical implications. Pharm Res 24:1227-1251.

Kumar P, Henikoff S and Ng PC (2009) Predicting the effects of coding non-synonymous variants on protein function using the SIFT algorithm. Nat Protoc 4:1073-1081.

Lane A, Soodyall H, Arndt S, Ratshikhopha M, Jonker E, Freeman C, Young L, Morar B and Toffie L (2002) Genetic substructure in South African Bantu-speakers: Evidence from autosomal DNA and Y-chromosome studies. Am J Phys Anthropol 119:175-185.

Leabman MK, Huang CC, De Young J, Carlson EJ, Taylor TR, de La Cruz M, Johns SJ, Stryke D, Kawamoto M, Urban TJ, et al. (2003) Natural variation in human membrane transporter genes reveals evolutionary and functional constraints. Proc Natl Acad Sci USA 100:5896-5901.

Leat N, Benjeddou M and Davison S (2004a) Nine-locus Y-chromosome STR profiling of Caucasian and Xhosa populations from Cape Town, South Africa. Forensic Sci Int 144:73-75.

Leat N, Ehrenrieich L, Benjeddou M and Davison S (2004b) Developments in the use of Y-chromosome markers in forensic genetics. Afr J Biotechnol 3:637-642.

Leat N, Ehrenreich L, Benjeddou M, Cloete K and Davison S (2007) Properties of novel and widely studied Y-STR loci in three South African populations. Forensic Sci Int 168:154161.

Li JZ, Absher DM, Tang H, Southwick AM, Casto AM, Ramachandran S, Cann HM, Barsh GS, Feldman M, CavalliSforza LL, et al. (2008) Worldwide human relationships inferred from genome-wide patterns of variation. Science 319:1100-1104.

Li Z, Zhang Z, He Z, Tang W, Li T, Zeng Z, He L and Shi Y (2009) A partition-ligation-combination-subdivision EM algorithm for haplotype inference with multiallelic markers: Update of the SHEsis (http://analysis. bio-x. cn). Cell Res 19:519-523.

Matimba A, Del-Favero J, Van Broeckhoven C and Masimirembwa C (2009) Novel variants of major drug-metabolising enzyme genes in diverse African populations and their predicted functional effects. Hum Genomics 3:169-190.

Ng PC and Henikoff S (2003) SIFT: Predicting amino acid changes that affect protein function. Nucleic Acids Res 31:3812-3814.

Nies AT, Koepsell H, Winter S, Burk O, Klein K, Kerb R, Zanger UM, Keppler D, Schwab M and Schaeffeler E (2009) Expression of organic cation transporters OCT1 (SLC22A1) and OCT3 (SLC22A3) is affected by genetic factors and cholestasis in human liver. Hepatology 50:1227-1240.

Nyakutira C, Röshammar D, Chigutsa E, Chonzi P, Ashton M, Nhachi $C$ and Masimirembwa C (2008) High prevalence of the CYP2B6 516G $\rightarrow \mathrm{T}(* 6)$ variant and effect on the population pharmacokinetics of efavirenz in HIV/AIDS outpatients in Zimbabwe. Eur J Clin Pharmacol 64:357-365.

Peakall R and Smouse PE (2012) GenAlEx 6.5: Genetic analysis in Excel. Population genetic software for teaching and research - An update. Bioinformatics 28:2537-2539. 
Rosenberg NA, Pritchard JK, Weber JL, Cann HM, Kidd KK, Zhivotovsky LA and Feldman MW (2002) Genetic structure of human populations. Science 298:2381-2385.

Sakata T, Anzai N, Shin HJ, Noshiro R, Hirata T, Yokoyama H, Kanai Y and Endou H (2004) Novel single nucleotide polymorphisms of organic cation transporter 1 (SLC22A1) affecting transport functions. Biochem Biophys Res Commun 313:789-793.

Shu Y, Brown C, Castro R, Shi R, Lin E, Owen R, Sheardown S, Yue L, Burchard E, Brett C, et al. (2007) Effect of genetic variation in the organic cation transporter 1, OCT1, on metformin pharmacokinetics. Clin Pharmacol Ther 83:273280 .

Shu Y, Leabman MK, Feng B, Mangravite LM, Huang CC, Stryke D, Kawamoto M, Johns SJ, DeYoung J, Carlson E, et al. (2003) Evolutionary conservation predicts function of variants of the human organic cation transporter, OCT1. Proc Natl Acad Sci USA 100:5902-5907.

Takeuchi A, Motohashi H, Okuda M and Inui K-i (2003) Decreased function of genetic variants, Pro283Leu and Arg287Gly, in human organic cation transporter hOCT1. Drug Metab Pharmacokinet 18:409-412.

Tishkoff SA, Reed FA, Friedlaender FR, Ehret C, Ranciaro A, Froment A, Hirbo JB, Awomoyi AA, Bodo J-M, Doumbo O, et al. (2009) The genetic structure and history of Africans and African Americans. Science 324:1035-1044.

Tzvetkov M, Vormfelde S, Balen D, Meineke I, Schmidt T, D Sehrt IS, Cacute H and Koepsell JB (2009) The effects of ge- netic polymorphisms in the organic cation transporters OCT1, OCT2, and OCT3 on the renal clearance of metformin. Clin Pharmacol Ther 86:299-306.

Warnich L, Drögemöller BI, Pepper MS, Dandara C and Wright GE (2011) Pharmacogenomic research in South Africa: Lessons learned and future opportunities in the rainbow nation. Curr Pharmacogenomics Person Med 9:191-207.

Wigginton JE, Cutler DJ and Abecasis GR (2005) A note on exact tests of Hardy-Weinberg equilibrium. Pharmacogenomics J 76:887-893.

Yong Y and Lin H (2005) SHEsis, a powerful software platform for analyses of linkage disequilibrium, haplotype construction, and genetic association at polymorphism loci. Cell Res 15:97-98.

Zhang L, Dresser MJ, Gray AT, Yost SC, Terashita S and Giacomini KM (1997) Cloning and functional expression of a human liver organic cation transporter. Mol Pharmacol 51:913-921.

\section{Internet Resources}

Ensembl database, http://www.ensembl.org (accessed April 2011).

Primer3 software, http://www.genome.wi.mit.edu/cgi-bin/ primer/primer3 (accessed April 2011).

Associate Editor: Maria Luiza Petzl-Erler

License information: This is an open-access article distributed under the terms of the Creative Commons Attribution License, which permits unrestricted use, distribution, and reproduction in any medium, provided the original work is properly cited. 